ISSN: 2302-8556

E-Jurnal Akuntansi Universitas Udayana

Vol.26.3.Maret (2019): 1717 -1740

DOI: https://doi.org/10.24843/EJA.2019.v26.i03.p02

\title{
Pengaruh Intellectual Capital Pada Nilai Perusahaan Dengan Kinerja Keuangan Sebagai Variabel Intervening
}

\author{
Ni Made Ayu Dwi Fitriasari ${ }^{1}$ \\ Maria Mediatrix Ratna Sari ${ }^{2}$ \\ ${ }^{1,2}$ Fakultas Ekonomi dan Bisnis Universitas Udayana (Unud), Bali, Indonesia \\ e-mail: a_nimade@ymail.com
}

\begin{abstract}
ABSTRAK
Penelitian ini bertujuan untuk mengetahui pengaruh intellectual capital pada nilai perusahaan dengan kinerja keuangan sebagai variabel intervening. Penelitian ini dilakukan pada perusahaan perbankan yang terdaftar di Bursa Efek Indonesia tahun 2014-2016, yaitu sebanyak 43 perusahaan. Sampel diambil menggunakan teknik non-probability sampling dengan metode purposive sampling, sehingga terpilih 33 perusahaan dengan 99 total amatan. Teknik analisi data menggunakan teknik analisis path. Hasil analisis membuktikan bahwa perusahaan yang mampu mengolah intellectual capital dengan baik akan mempengaruhi kinerja keuangan, perusahaan yang mampu mengolah intellectual capital dengan baik akan mempengaruhi nilai perusahaan, perusahaan yang mampu mengolah kinerja keuangan dengan baik akan mempengaruhi nilai perusahaan, serta kinerja keuangan mampu memediasi hubungan antara intellectual capital pada nilai perusahaan.
\end{abstract}

Kata Kunci : Intellectual capital, nilai perusahaan, kinerja keuangan

\begin{abstract}
This study aims to determine the effect of intellectual capital on firm value and financial performance as an intervening variable. This research was conducted on banking companies listed on the Indonesia Stock Exchange in 2014-2016, namely as many as 43 companies. Samples were taken using non-probability sampling techniques with purposive sampling method, so that 33 companies were selected with 99 total observations. Data analysis techniques use path analysis techniques. The results of the analysis prove that companies that are able to process intellectual capital well will affect financial performance, companies that are able to process intellectual capital well will affect the value of the company, companies that are able to process financial performance well will affect company value, and financial performance is able to mediate the relationship between intellectual capital in the value of the company.

Keywords :Intellectual capital, company value, financial performance
\end{abstract}

\section{PENDAHULUAN}

Perusahaan umumnya mempunyai suatu tujuan utama dalam jangka panjang yaitu meningkatkan kemakmuran pemilik atau para pemegang saham melalui peningkatan 
nilai perusahaan (Salvatore, 2011). Nilai perusahaan sering dikaitkan dengan harga saham, dimana semakin tinggi harga saham maka nilai perusahaan juga meningkat. Pada tahun 2016 terjadi penunuran harga saham pada sektor perbankan yang diperdagangkan di BEI yang terus menurun sejak tiga bulan silam, akibat isu pemangkasan NIM. Jatuhnya harga saham sektor perbankan menjadi salah satu faktor yang menahan laju indeks harga saham gabungan. Pada perdagangan saham di BEI, Selasa (17/5/2016). Karena jatuhnya saham-saham perbankan. Sepanjang tahun 2016 tiga saham emiten bank BUMN mencatatkan penurunan. Saham BMRI telah melemah 5,41\%, saham BBNI minus 13,63\%, dan saham BBRI 15,10\%. Selain bank BUMN yaitu saham BBYB minus 62,95\%.

Penurunan harga saham terjadi akibat pelaku pasar merespon negatif keinginan pemerintah meminta bank BUMN menaikan suku bunga kredit hingga rata-rata dibawah 10 persen pada akhir tahun 2016. Untuk mendorong perbankan mau menurunkan NIM, OJK menyiapkan aturan intensif dengan mempertimbangkan NIM beserta biaya operasional terhadap pendapatan operasional (BOPO) perbankan. Kasus ini mencerminkan dimana investor melihat adanya penurunan performa perusahaan perbankan yang menyebabkan menurunnya minat investor untuk berinvestasi pada perusahaan tersebut, serta menurunkan nilai perusahaan.

Dalam dunia bisnis para pelaku bisnis menyadari bahwa kemampuan bersaing tidak hanya pada kepemilikan sumber daya berwujud yang dimilikinya, namun lebih kepada informasi, inovasi dan knowledge sumber daya manusia yang diimilikinya 
ISSN: 2302-8556

E-Jurnal Akuntansi Universitas Udayana

Vol.26.3.Maret (2019): $1717-1740$

(Jessika, 2012). Salah satu pendekatan yang digunakan dalam penilaian dan pengukuran aset tidak berwujud tersebut adalah intellectual capital (Subkhan dan Citraningrum, 2010).

Fenomena intellectual capital berkembang setelah munculnya PSAK No. 19 (revisi 2010) tentang aktiva tidak berwujud, walaupun tidak dinyatakan secara eksplisit sebagai intellectual capital, namun telah menjadi perhatian serius dimana aset yang tak berwujud adalah aset non moneter yang teridentifikasi tanpa wujud fisik. Aset tak berwujud digunakan dalam menghasilkan atau menyerahkan barang dan jasa yang kemudian disewakan kepada pihak lainnya atau untuk tujuan administratif. Pada paragraph 09 PSAK No. 19 tentang aktiva tidak berwujud disebutkan terdiri dari pengetahuan, teknologi, lisensi, hak kekayaan intelektual, implikasi sistem baru, pengetahuan mengenai pasar dan merek dagang. Banyak perusahaan mulai memperhatikan aktiva tidak berwujud sebagai strategi bisnis untuk mencapai keunggulan kompetitif yang berdampak pada penerapan knowledge based business (Dwipayani, 2014).

Penelitian Pulic (1998), pengukuran intellectual capital secara tidak langsung dengan menggunakan Value Added Intelecctual Coefficient $\left(\mathrm{VAIC}^{\mathrm{TM}}\right.$ ), yaitu suatu ukuran untuk menilai efesiensi dari nilai tambah sebagai hasil dari kemampuan intelektual suatu perusahaan.

Penelitian mengenai intellectual capital terhadap nilai perusahaan dan kinerja keuangan dilakukan namun memperoleh hasil yang bervariasi. Sudibya and Restuti (2014), Nurdinia (2013), serta Putra (2012) membuktikan adanya pengaruh positif 
antara intellectual capital terhadap nilai perusahaan. Sedangkan hasil yang berbeda ditunjukkan oleh Lestari dan Sapitri (2016), Faza dan Hidayah (2014), serta Wahyu (2011) yang membuktikan bahwa intellectual capital tidak berpengaruh positif terhadap nilai perusahaan.

Untuk variabel kinerja keuangan, penelitian yang dilakukan oleh Faradina dan Gayatri (2016) meneliti tentang pengaruh modal intelektual terhadap kinerja keuangan pada perusahaan yang tergabung dalam Indeks LQ45 menggunakan metode VAIC $^{\mathrm{TM}}$. Hasil penelitian menyatakan bahwa intellectual capital berpengaruh positif terhadap kinerja keuangan perusahaan. Serta penelitian yang dilakukan oleh Simarmata dan Subowo (2016) yaitu menyatakan bahwa VAIC ${ }^{\mathrm{TM}}$ berpengaruh positif terhadap kinerja keuangan. Dari hasil penelitian menunjukkan adanya keterkaitan hubungan antara intellectual capital dengan kinerja keuangan perusahaan.

Penelitian ini mereplikasi penelitian dari Sudibya dan Restuti (2014) untuk memperkuat hasil penelitian mengenai pengaruh intellectual capital pada nilai perusahaan dengan kinerja keuangan sebagai variabel intervening. Karena pada penelitian terdahulu memberikan hasil yang tidak konsisten yang memungkinkan adanya penyebab dari variabel yang lain yang dapat memediasi antara IC dengan nilai perusahaan yaitu kinerja keuangan.

Proksi yang dapat mengukur IC dalam penelitian ini yaitu $\mathrm{VAIC}^{\mathrm{TM}}$ mengacu pada penelitian Chen et al. (2005), Ulum (2007), serta Fajarini dan Firmansyah (2012). Yang membedakan penelitian ini dengan sebelumnya penggunaan ROA 
ISSN: 2302-8556

E-Jurnal Akuntansi Universitas Udayana

Vol.26.3.Maret (2019): 1717 -1740

sebagai proksi atas kinerja keuangan dan data yang digunakan adalah sektor perbankan yang terdaftar di BEI periode 2014-2016.

Sektor perbankan sebagai unit analisis karena sektor perbankan menyajikan data laporan keuangan publikasi yang dapat diakses setiap saat, selain itu sektor perbankan merupakan salah satu sektor yang memanfaatkan potensi sumber daya manusia daripada aset fisik yang dimilikinya (Pramestiningrum, 2013).

Stakeholder theory menyatakan perusahaan bukanlah entitas yang hanya beroperasi untuk kepentingan sendiri, namun harus memberikan manfaat bagi stakeholder (Ghozali dan Chariri, 2007). Stakeholder dalam hal ini, memiliki kewenangan untuk mempengaruhi manajemen dalam proses pemanfaatan seluruh potensi yang dimiliki oleh organisasi. Karena hanya dengan pengelolaan yang baik dan maksimal atas seluruh potensi ilmiah organisasi akan dapat menciptakan value added untuk kemudian mendorong kinerja keuangan dan nilai perusahaan yang merupakan orientasi para stakeholder dalam mengintervensi manajemen (Wahyu, 2011).

Penciptaan nilai dapat dilakukan dengan menggunakan seluruh potensi yang dimiliki perusahaan. Dengan pengendalian yang baik atas seluruh potensi dapat menimbulkan nilai tambah yang dapat meningkatkan kinerja keuangan perusahaan dan meningkatkan pertumbuhan perusahaan sehingga nilai perusahaan di mata stakeholder akan meningkat. Sehingga nilai tambah dan return dapat menjelaskan kekuatan teori stakeholder dalam kaitannya dengan pengukuran kinerja perusahaan. 
Teori Sumber Daya merupakan suatu pemikiran yang berkembang dalam teori manajemen strategik dan keunggulan kompetitif perusahaan yang meyakini bahwa perusahaan akan mencapai keunggulan apabila memiliki sumber daya yang unggul (Solikhah dkk, 2010). Keunggulan kompetitif perusahaan diperoleh dari kemampuan perusahaan untuk merakit dan memanfaatkan kombinasi sumber daya yang tepat (Chang et al, 2011). Perusahaan dipersepsikan sebagai kumpulan aset maupun kemampuan berwujud dan tidak berwujud (Firer dan Williams, 2003). Menurut teori sumber daya dengan memiliki kinerja keuangan yang baik akan menunjukkan kemampuan perusahaan dalam menggunakan aset fisik dan aset non fisik secara efektif dan efesien.

Pandangan teori RBT dalam mencapai keunggulan dalam bersaing sumber daya perusahaan harus terdiri dari 4 atribut, yaitu langka, bernilai tinggi, tidak mudah tergantikan, dan tidak mudah ditiru (Bridoux, 2004). IC merupakan sumber daya pengetahuan yang bersumber dari karyawan, proses, pelanggan, termasuk teknologi yang dapat dikelola oleh perusahaan demi penciptaan nilai tambah bagi perusahaan (Bukh et al., 2005). Mondal dan Ghosh (2012) beragumen bahwa istilah intellectual capital merujuk pada seluruh aset tidak berwujud serta faktor-faktor bisnis perusahaan yang tidak berwujud, yang mana berdampak signifikan pada kinerja serta kesuksesan bisnis perusahaan secara keseluruhan. Perusahaan yang mengelola aset fisik dan finansialnya memerlukan kemampuan yang mumpuni dari IC, maka selain menghasilkan suatu produk yang bernilai diperlukan kemampuan dan daya pikir 
ISSN: 2302-8556

E-Jurnal Akuntansi Universitas Udayana

Vol.26.3.Maret (2019): 1717 -1740

karyawan, sekaligus bagaimana mengelola organisasi dan menjalin hubungan dengan pihak eksternal (Kartika dan Hatane, 2013).

Bontis et al. (2000) Intellectual capital terbagi kedalam tiga elemen yaitu human capital merupakan komponen IC yang paling kritis dalam hal memprediksi kinerja operasional perusahaan Ngari et al. (2016), structural capital merupakan kemampuan organisasi atau perusahaan dalam memenuhi proses rutinitas perusahaan dan strukturnya yang mendukung usaha karyawan untuk menghasilkan kinerja intelektual yang optimal serta kinerja bisnis secara keseluruhan, dan customer capital yaitu perusahaan harus menjaga hubungan dengan pihak luar.

Suatu pendekatan yang secara tidak langsung bisa digunakan untuk mengukur intellectual capital perusahaan dikembangkan oleh Pulic pada tahun 1998. Metode pengukuran ini dikenal dengan istilah value added intellectual coefficient (VAIC). Metode VAIC ini dirancang secara khusus untuk mengevaluasi efisisensi vaue added (VA) dengan total sumber daya perusahaan dan masing-masing komponen sumber daya utama. Metode ini digunakan secara luas karena data-data yang diperlukan untuk melakukan perhitungan tersedia dalam laporan keuangan pada umumnya (Razafindrambinina dan Anggreni, 2011).

Kinerja keuangan merupakan sebuah tampilan yang memberikan informasi terkait keadaan dan kondisi keuangan suatu perusahaan dalam periode tertentu (Fauzi, 2016). Seperti dengan membuat suatu laporan keuangan yang telah memenuhi standar dan ketentuan dalam Standar Akunntansi Keuangan (SAK) (Fahmi, 2011). Kinerja keuangan merupakan salah satu alat ukur yang digunakan untuk mengukur suatu 
kualitas perusahaan. Pengukuran terhadap kinerja perusahaan diperlukan untuk mengetahui apakah kinerja perusahaan baik atau buruk.

Kinerja perusahaan dalam penelitian ini Return On Asset (ROA) sebagai variabel intervening. ROA merupakan rasio yang diukur berdasarkan perbandingan antara laba setelah pajak dengan total aktiva perusahaan. Penelitian Putri (2017) menunjukkan kinerja keuangan berpengaruh pada nilai perusahaan dan Sudibya da Restuti (2014) menunjukkan bahwa kinerja keuangan dapat memediasi hubungan antara modal intelektual dengan nilai perusahaan.

Tujuan utama perusahaan yaitu meningkatkan nilai perusahaan yang berarti dengan meningkatkan kemakmuran pemilik perusahaan atau para pemegang saham (Brigham dan Houston, 2010). Meningkatkan nilai perusahaan sama dengan meningkatkan harga saham. Nilai perusahaan sering dikaitkan dengan harga saham, harga saham yang tinggi maka nilai perusahan juga tinggi dengan otomatis return perusahaan akan tinggi.

Proksi dalam variabel nilai perusahaan menggunakan PBV. PBV yang tinggi akan membuat pasar percaya atas prospek perusahaan ke depan. Hal itu juga menjadi keinginan para pemilik perusahaan, sebab nilai perusahaan yang tinggi akan membawa kemakmuran para pemegang saham juga tinggi. Dengan begitu, perusahaan harus mengoptimalkan harga perusahaan, tidak menjual harga perusahaan terlalu tinggi maupun tidak menjual harga perusahaan terlalu rendah untuk menarik perhatian investor. 
ISSN: 2302-8556

Perusahaan yang mampu mengelola pengetahuan, keterampilan dan keahlian modal manusia diyakini mampu menciptakan nilai tambah serta mampu menciptakan keunggulan kompetitif dengan melakukan inovasi, penelitian dan pengembangan yang akan meningkatkan kinerja keuangan perusahaan. Dalam teori RBT, perusahaan yang unggul dalam persaingan usaha dan mendapatkan kinerja keuangan yang baik maka perusahaan harus dapat mengelola dan memanfaatkan aset fisik dan aset tidak fisik. Sehingga sesuai dengan stakeholder theory yaitu manajemen perusahaan diharapkan dapat melakukan aktivitas yang dianggap penting oleh para stakeholder dan melaporkan kembali aktivitas kepada para stakeholder karena seluruh stakeholder memiliki hak untuk mendapatkan informasi mengenai aktivitas organisasi. Informasi yang bisa didapatkan yaitu intellectual capital. Intellectual capital diyakini dapat berperan penting bagi perusahaan dalam mendorong peningkatan kinerja keuangan dan nilai perusahaan.

Pada penelitian Belkaoui (2003), Mehralian et al. (2012), Zulyati dan Arya (2011), Neha dan Das (2017) yaitu bahwa IC berpengaruh positif terhadap kinerja keuangan.

$\mathrm{H}_{1}$ : Intellectual Capital berpengaruh positif pada kinerja keuangan perusahaan

Teori stakeholder menjelaskan bahwa seluruh aktifitas perusahaan bermuara pada penciptaan nilai, kepemilikan serta pemanfaatan sumber daya intelektual memungkinkan perusahaan mencapai keunggulan bersaing dan meningkatkan nilai tambah (Sunarsih dan Mendra, 2012). Para pemegang saham akan lebih menghargai perusahaan yang mampu menciptakan nilai. Para stakeholder akan menghargai 
perusahaan yang memiliki IC yang unggul, karena IC yang unggul akan membantu perusahaan untuk memenuhi kepentingan seluruh stakeholder. Investor akan memberikan apresiasi atas IC yang unggul dengan berinvestasi pada perusahaan tersebut. Dengan adanya pertambahan investasi maka akan berdampak pada naiknya nilai perusahaan.

Chen et al. (2005) dengan penelitiannya menunjukkan bahwa IC berpengaruh positif pada nilai pasar perusahaan. Begitu pula dengan Nurdinia (2013) yaitu IC berpengaruh positif pada nilai perusahaan.

$\mathrm{H}_{2}$ : Intellectual Capital berpengaruh positif pada nilai perusahaan

Tujuan teori stakeholder yaitu membantu manajer perusahaan dalam meningkatkan nilai dari dampak aktifitas-aktifitas dan meminimalkan kerugian bagi stakeholder. Dengan memaksimalkan kinerja perusahaan maka akan meningkatkan nilai perusahaan. Apabila perusahaan dapat meningkatkan keuntungan, maka harga saham akan meningkat. Dengan adanya keuntungan yang meningkat akan menciptakan keunggulan daya saing perusahaan. Dengan harga saham yang tinggi para investor akan mengapresiasikan kinerja perusahaan.

Ayu (2017) dengan penelitiannya menunjukkan ROA memiliki pengaruh positif pada nilai perusahaan. Hasil yang sama diperoleh melalui penelitian Pratama dan Wiksuana (2016) yaitu bahwa kinerja perusahaan memiliki pengaruh positif terhadap nilai perusahaan.

$\mathrm{H}_{3}$ : Kinerja Keuangan berpengaruh positif pada Nilai Perusahaan. 
ISSN: 2302-8556

E-Jurnal Akuntansi Universitas Udayana

Vol.26.3.Maret (2019): $1717-1740$

Dalam teori RBT berasumsi bahwa perusahaan dapat bersaing secara kompetitif apabila perusahaan tersebut dapat mengelola dan memanfaatkan sumber daya yang dimilikinya dengan efektif dan efesien. Dengan mengelola sumber daya secara efektif dan efesien akan meningkatkan kinerja perusahaan yang akan direspon positif oleh stakeholder. Nilai perusahaan dapat dilihat dari harga saham perusahaan. Jika respon stakeholder baik maka nilai perusahaan akan semakin baik.

Firer dan Williams (2003), Chen et al. (2005) dan Tan et al. (2007) membuktikan bahwa intellectual capital berpengaruh positif terhadap kinerja keuangan dan nilai perusahaan. Bertentangan dengan Yuniasih dkk. (2011) tidak berhasil membuktikan bahwa intellectual capital berpengaruh pada nilai pasar perusahaan. Penelitian ini menambahkan variabel intervening yaitu kinerja keuangan untuk mengetahui langsung atau tidak langsung intellectual capital pada nilai perusahaan. Hal ini didukung oleh Sunarsih dan Mendra (2012) menunjukkan bahwa kinerja keuangan mampu memediasi hubungan antara modal intelektual dan nilai perusahaan. Pasar akan memberikan penilaian yang lebih tinggi kepada perusahaan yang memiliki kinerja keuangan yang meningkat, kinerja keuangan yang meningkat akan direspon positif oleh pasar sehingga meningkatkan nilai perusahaan.

$\mathrm{H}_{4}$ : Kinerja keuangan memediasi hubungan antara intellectual capital dan nilai perusahaan. 


\section{METODE PENELITIAN}

Penelitian ini dilakukan pada perusahaan perbankan yang terdaftar di BEI tahun 2014-2016 sebagai populasi. Pengambilan sampel dilakukan dengan teknik purposive sampling. Data akan diolah menggunakan aplikasi SPSS untuk mengetahui hasil dari hipotesis yang telah dibuat.

Populasi dalam penelitian ini adalah seluruh perusahaan perbankan yang terdaftar di Bursa Efek Indonesia tahun 2014-2016. Sampel dalam penelitian ini ditentukan menggunakan metode non probability sampling dengan teknik purposive sampling dimana pemilihan sampel tidak acak dengan tujuan untuk mendapatkan sampel sesuai dengan kriteria yang ditentukan.

Tabel 1.

\section{Penentuan Sampel Penelitian}

\begin{tabular}{clc}
\hline No. & \multicolumn{1}{c}{ Kriteria } & Jumlah Perusahaan \\
\hline $1 . \quad \begin{array}{l}\text { Perusahaan perbankan yang terdaftar di Bursa Efek Indonesia } \\
\text { selama periode penelitian }\end{array}$ & 43 \\
2. $\quad \begin{array}{l}\text { Perusahaan perbankan yang laporan keuangannya tidak ditemukan } \\
\text { secara berturut-turut selama periode penelitian }\end{array}$ & $(5)$ \\
3. $\quad \begin{array}{l}\text { Perusahan perbankan yang mengalami kerugian atau laba negatif } \\
\text { selama periode penelitian }\end{array}$ & $(5)$ \\
Sampel Penelitian & 33 \\
Total Sampel Penelitian selama 3 tahun (periode 2014-2016) & 99
\end{tabular}

Sumber: www.idx.co.id, 2018

Untuk menguji pengaruh variabel intervening digunakan metode analisis jalur (path analysis). Analisis jalur merupakan perluasan dari analisis regresi linier berganda. Analisis jalur digunakan jika terdapat variabel mediasi (Ghozali, 2013).

Uji sobel merupakan alat analisis untuk menguji signifikansi dari hubungan tidak langsung antar variabel independen dengan variabel dependen yang dimediasi 
oleh variabel mediator (Preacher dan Hayes, 2004). Uji Sobel diformulasikan dengan rumus sebagai berikut :

$$
\mathrm{Sab}=\sqrt{b^{2} S a^{2}+a^{2} S b^{2}+S a^{2} S b^{2}}
$$

Keterangan :

a $\quad=$ koefisien $\mathrm{X}$ terhadap $\mathrm{Z}$

$\mathrm{b} \quad=$ koefisien $\mathrm{Z}$ terhadap $\mathrm{Y}$

$\mathrm{Sa}=$ Standar error koefisien a

$\mathrm{Sb}=$ Standar error koefisien $\mathrm{b}$

Untuk menguji signifikansi pengaruh tidak langsung, maka perlu menghitung

nilai t dari koefisien ab dengan rumus sebagai berikut:

$$
\mathrm{t}=\frac{\mathrm{ab}}{\mathrm{Sab}}
$$

Hasil analisis akan membandingkan nilai $t_{\text {hitung }}$ dengan $t_{\text {tabel. }}$. Jika $t_{\text {hitung }}$ lebih besar dari $t_{\text {tabel }}$ dengan tingkat signifikansi 0,05 yaitu sebesar 1,96 maka dapat disimpulkan pengaruh mediasi (Ghozali, 2013).

\section{HASIL DAN PEMBAHASAN}

Hasil statistik deskripsif variabel penelitian menyampaikan informasi mengenai karakteristik variabel penelitian yang terdiri dari jumlah pengamatan, nilai minimum, nilai maksimum, nilai rata dan standar deviasi. Hasil statistik deskriptif variabel penelitian ini dapat dilihat pada Tabel 2. 
Tabel 2.

Statistik Deskriptif

\begin{tabular}{lrrrrr}
\hline & N & Minimum & \multicolumn{1}{c}{ Maximum } & \multicolumn{1}{c}{ Mean } & \multicolumn{1}{c}{ Std. Deviation } \\
\hline IC & 99 & 1.2547 & 7.0145 & 2.881991 & 1.2713983 \\
Nilai Perusahaan & 99 & .3332 & 3037.9924 & 32.122564 & 305.1853267 \\
Kinerja Keuangan & 99 & .0008 & .1643 & .013474 & .0174879 \\
Valid N (listwise) & 99 & & & & \\
\hline Sumber: Data diolah, 2018 & & & & &
\end{tabular}

Variabel Nilai Perusahaan (Y) memiliki nilai minimum sebesar 0,3332 yang dimiliki oleh BNBA tahun 2015, sedangkan nilai maksimum sebesar 3037,9924 yang dimiliki oleh BBMD tahun 2014, dengan mean sebesar 32,122564 dan standar deviasi sebesar 305,1853267. Variabel Intellectual Capital (X) memiliki nilai minimum sebesar 1,2547 yang dimiliki oleh DNAR tahun 2014, sedangkan nilai maksimum sebesar 7,0145 yang dimiliki oleh PNBS tahun 2014 dengan mean sebesar 2,881991 dan standar deviasi sebesar 1,2713983. Variabel Kinerja Keuangan (Z) memiliki nilai minimum sebesar 0,0008 yang dimiliki oleh AGRS tahun 2016, sedangkan nilai maksimum sebesar 0,1643 yang dimiliki oleh BBYB tahun 2016 dengan mean sebesar 0,013474 dan standar deviasi sebesar 0,0174879.

Perhitungan analisis jalur dilakukan dengan analisis regresi melalui software SPSS 18.0 for Windows, diperoleh hasil yang ditunjukan pada Tabel 3. 
ISSN: 2302-8556

E-Jurnal Akuntansi Universitas Udayana

Vol.26.3.Maret (2019): $1717-1740$

\section{Tabel 3.}

Hasil Path Analysis Struktur 1

\begin{tabular}{lcccc}
\hline \multicolumn{1}{c}{ Variabel } & $\begin{array}{c}\text { Unstandardized } \\
\text { Coefficients }\end{array}$ & Std. Error & t hitung & Sig. uji t \\
\hline (Constant) & $-0,094$ & 0,085 & $-1,104$ & 0,272 \\
Intellectual Capital $(\mathrm{X})$ & 0,376 & 0,088 & 4,290 & 0,000 \\
R Square & 0,159 & & & \\
Adjusted R Square & 0,151 & & & \\
F Statistik & 18,403 & & & \\
Signifikansi Uji F & 0,000 & & & \\
\hline
\end{tabular}

Sumber: Data diolah, 2018

Berdasarkan hasil analisis jalur struktur pertama seperti disajikan pada Tabel, maka dapat dibuat persamaan struktural sebagai berikut :

$$
\mathrm{ROA}=0,376 \mathrm{VAIC}^{\mathrm{TM}}+\mathrm{e}_{1}
$$

Berdasarkan hasil analisis statistik dalam penelitian ini menunjukkan bahwa hipotesis pertama $\left(\mathrm{H}_{1}\right)$ dapat diterima dan menyimpulkan bahwa IC memiliki pengaruh positif pada variabel kinerja keuangan dengan memiliki pengaruh sebesar 0,376 atau $37,6 \%$. Hasil ini menunjukkan bahwa perusahaan yang mampu mengelola IC dengan baik maka akan meningkatkan pada kinerja keuangan perusahaan.

Tabel 4.

Hasil Path Analysis Struktur 2

\begin{tabular}{lcccc}
\hline \multicolumn{1}{c}{ Variabel } & Unstandardized Coefficients & Std. Error & t hitung & Sig. uji t \\
\hline (Constant) & $-0,036$ & 0,083 & $-0,429$ & 0,669 \\
Intellectual Capital (X) & 0,196 & 0,092 & 2,127 & 0,036 \\
Kinerja keuangan (Z) & 0,288 & 0,098 & 2,936 & 0,004 \\
R Square & 0,183 & & & \\
Adjusted R Square & 0,166 & & & \\
F Statistik & 10,786 & & & \\
Signifikansi Uji F & 0,000 & & &
\end{tabular}

Sumber: Data diolah, 2018

Berdasarkan hasil analisis jalur struktur kedua yang disajikan pada Tabel, maka dapat dibuat persamaan struktural sebagai berikut : 


$$
\mathrm{PBV}=0,196 \mathrm{VAIC}^{\mathrm{TM}}+0,288 \mathrm{ROA}+\mathrm{e}_{2}
$$

Berdasarkan hasil analisis statistik dalam penelitian ini menunjukkan bahwa hipotesis kedua $\left(\mathrm{H}_{2}\right)$ dapat diterima dan menyimpulkan bahwa variabel IC memiliki pengaruh positif terhadap variabel nilai perusahaan dengan memiliki pengaruh sebesar 0,196 atau 19,6\%.

Berdasarkan hasil analisis statistik dalam penelitian ini menunjukkan bahwa hipotesis ketiga $\left(\mathrm{H}_{3}\right)$ dapat diterima dan menyimpulkan bahwa variabel kinerja keuangan memiliki pengaruh positif terhadap variabel nilai perusahaan dengan memiliki pengaruh sebesar 0,288 atau $28,8 \%$.

Sebelum menyusun diagram jalur akhir, terlebih dahulu dihitung koefisien determinasi sebagai berikut:

\section{Tabel 5.}

\section{Hasil Uji Koefisien Determinasi Struktur 1}

\begin{tabular}{lcccc}
\hline Model & & \multicolumn{2}{c}{$\begin{array}{c}\text { Adjusted R } \\
\text { R quare }\end{array}$} & $\begin{array}{c}\text { Std. Error of the } \\
\text { Estimate }\end{array}$ \\
\hline 1 & R Square & .151 & .84706581 \\
\hline Sumber: Data diolah, 2018 & & & &
\end{tabular}

Tabel 5 menggambarkan besarnya koefisien determinasi pada struktur yang pertama. Berdasarkan tabel 5, diperoleh hasil bahwa nilai koefisien determinasi pada persamaan pertama adalah 0,159 atau $15,9 \%$, hal ini mengindikasikan bahwa kinerja keuangan dipengaruhi oleh intellectual capital, sedangkan sisanya sebesar $84,1 \%$ dijelaskan oleh faktor lain yang tidak dimasukkan ke dalam model. 
ISSN: 2302-8556

E-Jurnal Akuntansi Universitas Udayana

Vol.26.3.Maret (2019): $1717-1740$

Tabel 6.

Hasil Uji Koefisien Determinasi Struktur 2

Model

Adjusted R Std. Error of the

\begin{tabular}{|c|c|c|c|c|}
\hline & $\mathrm{R}$ & R Square & Square & Estimate \\
\hline 1 & $.428^{\mathrm{a}}$ & .183 & .166 & .81721743 \\
\hline
\end{tabular}

Tabel 6 menggambarkan besarnya koefisien determinasi pada struktur yang pertama. Berdasarkan tabel 6, diperoleh hasil bahwa nilai koefisien determinasi pada persamaan kedua adalah 0,183 atau $18,3 \%$, hal ini mengindikasikan bahwa nilai perusahaan dipengaruhi oleh intellectual capital dan kinerja keuangan, sedangkan sisanya sebesar $81,7 \%$ dijelaskan oleh faktor lain yang tidak dimasukkan ke dalam model.

Perhitungan pengaruh antar variabel dapat dilihat dalam tabel 7 sebagai berikut:

\section{Tabel 7.}

Pengaruh Langsung, Pengaruh Tidak Langsung serta Pengaruh Total Variabel Penelitian

\begin{tabular}{clcc} 
Pengaruh Variabel & $\begin{array}{c}\text { Pengaruh } \\
\text { Langsung }\end{array}$ & $\begin{array}{c}\text { Pengaruh Tidak Langsung } \\
(\mathrm{Y} 1)(\beta 1 \times \beta 3)\end{array}$ & Pengaruh Total \\
\hline $\mathrm{VAIC}^{\mathrm{TM}} \rightarrow \mathrm{ROA}$ & 0,376 & - & 0,376 \\
$\mathrm{VAIC}^{\mathrm{TM}} \rightarrow \mathrm{PBV}$ & 0,196 & 0,108 & 0,304 \\
$\mathrm{ROA} \rightarrow \mathrm{PBV}$ & 0,288 & - & 0,288 \\
\hline
\end{tabular}

Sumber: Data diolah, 2018

Tabel 7 menunjukkan bahwa pengaruh langsung variabel Intellectual Capital terhadap nilai perusahaan sebesar 0,196 . Sedangkan pengaruh tidak langsung variabel Intellectual Capital terhadap nilai perusahaan melalui Kinerja keuangan perusahaan sebesar 0,108. Jadi pengaruh total variabel Intellectual Capital terhadap nilai 
perusahaan melalui Kinerja keuangan adalah sebesar 0,304. Jadi dapat disimpulkan bahwa lebih besar total pengaruh Intellectual Capital terhadap nilai perusahaan yang melalui Kinerja keuangan, daripada pengaruh langsung Intellectual Capital terhadap nilai perusahaan tanpa melalui variabel Kinerja keuangan. Hasil penelitian ini berhasil membuktikan dugaan peneliti mengenai adanya pengaruh kinerja keuangan yang memediasi hubungan intellectual capital dan niali perusahaan sehingga hipotesis empat $\left(\mathrm{H}_{4}\right)$ diterima.

Uji sobel dirumuskan dengan persamaan dan dapat dihitung dengan menggunakan aplikasi Microsoft Exel 2007. Bila nilai kalkulasi T lebih besar dari 1,96, maka variabel mediator dinilai secara signifikan memediasi hubungan antara variabel terikat dan variabel bebas.

$$
\begin{aligned}
& S_{a b}=\sqrt{b^{2} S a^{2}+a^{2} S b^{2}+S a^{2} S b^{2}} \\
& S_{a b}=\sqrt{(0,288)^{2}(0,088)^{2}+(0,376)^{2}(0,098)^{2}+(0,088)^{2}(0,098)^{2}} \\
& S_{a b}=\sqrt{0,00064+0,00136+0,00007} \\
& S_{a b}=0,045546
\end{aligned}
$$

Untuk menguji signifikansi pengaruh tidak langsung maka menghitung nilai t dari koefisien ab dengan rumus sebagai berikut :

$$
\begin{aligned}
t & =\frac{a b}{S a b} \\
& =\frac{(0,376)(0,288)}{0,045546} \\
t & =2,3775 \text { dengan signifikansi } 0,017
\end{aligned}
$$


ISSN: 2302-8556

E-Jurnal Akuntansi Universitas Udayana

Vol.26.3.Maret (2019): 1717 -1740

Hasil analisis menunjukkan t hitung sebesar 2,3775 lebih besar dari t tabel 1,96. Maka kinerja keuangan (Z) merupakan variabel yang memediasi Intellectual Capital (X) terhadap nilai perusahaan (Y).

\section{SIMPULAN}

Temuan pertama IC aberpengaruh positif pada kinerja keuangan. Semakin tinggi IC maka dapat menaikan kinerja keuangan perusahaan. Ketika kinerja keuangan mengalami kenaikan akibat IC, maka perusahaan akan mampu mengelola aset yang dimiliki secara maksimal. IC berpengaruh positif pada nilai perusahaan. Semakin tinggi IC maka akan menaikan nilai perusahaan. Dengan memanfaatkan sumber daya perusahaan yang baik akan mendorong pembentukan nilai tambah bagi perusahaan. Kinerja keuangan perpengaruh positif pada nilai perusahaan. Semakin tinggi kinerja keuangan makan dapat menaikan nilai perusahaan. Memungkinkan respon kepada investor sehingga meningkatkan daya tarik investor berdampak pada harga saham yang meningkat. Meningkatnya harga saham akan meningkatkan nilai perusahaan. Kinerja keuangan mampu memediasi hubungan antara IC terhadap kinerja keuangan. Investor telah memberikan penilaian yang lebih tinggi kepada perusahaan yang memiliki kinerja keuangan yang lebih tinggi. Dengan meningkatnya kinerja keuangan maka perusahaan mampu mengelola sumber daya intelektualnya dengan efektif dan efesien. 
Saran yang dapat diberikan dalam penelitian ini adalah manajemen perusahaan disarankan untuk tetap atau lebih meningkatkan lagi upaya pengelolaan intellectual capital. Dengan memberikan program pelatihan kepada karyawan.

\section{REFERENSI}

Ayu, Dea Putri. 2017. Pengaruh Profitabilitas Terhadap Nilai Perusahaan Dengan Corporate Social Responbility Sebagai Variabel Mediasi Pada Perusahaan Pertambangan. E-Jurnal Manajemen Universitas Udayana, 6(2), hal. 11121138 .

Belkaoui, Ahmed Riahi. 2003. Intellectual Capital and Firm Performance of U.S. Multinational Firms: A Study of the Resource-Based and Stakeholder Views 1. Journal of Intellectual Capital, pp. 1-26.

Bontis, Nick, William Chua Chong Keow, and Stanley Richardson. 2000. Intellectual Capital and Business Performance in Malaysian Industry. Journal of Intellectual Capital.

Bridoux, Flore. 2004. A Resource-Based Approach to Performance and Competition : An Overview of the Connections between Resources and Competition. Journal of d'Administration et de Gestion, Universite Catholique de Louvain, Belgium, pp: $1-21$.

Brigham and Houston. 2010. Dasar-Dasar Manajemen Keuangan Buku 1 (Edisi 11). Jakarta: Salemba Empat.

Bukh, Per Nikolaj, Christian Nielsen, Peter Gormsen, and Jan Mouritsen. 2005. Disclosure of Information on Intellectual Capital in Danish IPO Prospectuses. Accounting, Auditing \& Accountability Journal, 18(6), pp: 131-141.

Chang, William S. and Jasper J. Hsieh. 2011. Intellectual Capital and Value CreationIs Innovation Capital a Missing Link? International Journal of Bussiness and Management, 6(2), pp: 3-12.

Chen, Ming-chin, Shu-Ju Cheng, and Yuhchang Hwang. 2005. An Empirical Investigation of the Relationship between Intellectual Capital and Firms , Market Value and Financial Performance. Journal of Intellectual Capital, 6(2), pp: 159-176. 
ISSN: 2302-8556

E-Jurnal Akuntansi Universitas Udayana Vol.26.3.Maret (2019): $1717-1740$

Dwipayani, Chrisnatty Chandra. 2014. Pengaruh Intellectual Capital Terhadap Profitabilitas Dan Kinerja Pasar (Studi Empiris Pada Perusahaan Perdagangan Dan Jasa). Skripsi Pada Program Sarjana Fakultas Ekonomi Dan Bisnis Universitas Dipenogoro.

Fahmi, Irham. 2011. Analisis Kinerja Keuangan. Jakarta: Alfabeta.

Fajarini, Indah and Riza Firmansyah. 2012. Pengaruh Intellectual Capital Terhadap Kinerja Keuangan Perusahaan (Studi Empiris Perusahaan LQ45). Jurnal Dinamika Akuntansi, 4(1), hal. 1-12.

Faradina, Ike and Gayatri. 2016. Pengaruh Intellectual Capital Dan Intellectual Capital Disclosure Terhadap Kinerja Keuangan Perusahaan. E-Jurnal Akuntansi Universitas Udayana, 15(2), hal. 1623-1653.

Fauzi, Achmad. 2016. Analisis Pengaruh Intellectual Capital Terhadap Nilai Perusahaan Dengan Kinerja Keuangan Sebagai Variabel Intervening (Studi Kasus Pada Perusahaan Yang Terdaftar Dalam Indeks LQ45 Periode 20092014). Skripsi Pada Program Studi Manajemen Fakultas Ekonomika Dan Bisnis Universitas Islam Negeri Syarif Hidayatullah.

Faza, Muhammad Fardin and Erna Hidayah. 2014. Pengaruh Intellectual Capital Terhadap Profitabilitas, Produktivitas, Dan Nilai Perusahaan Pada Perusahaan Perbankan Yang Terdaftar Di Bursa Efek Indonesia (BEI). Jurnal Ekonomi Dan Bisnis Islam, VIII(2), hal. 186-199.

Firer, Steven and S.Mitchell Williams. 2003. Intellectual Capital and Traditional Measures of Corporate Performance. Journal of Intellectual Capital, 4(3), pp. 348-60.

Ghozali, Imam. 2013. Aplikasi Analisis Multivariate Dengan Program SPSS. Edisi Ketujuh. Semarang: Badan Penerbit Universitas Dipenegoro.

Ghozali, Imam and A. Chariri. 2007. Teori Akuntansi. Semarang: Badan Penerbit Universitas Dipenogoro.

Jessika, Oktavia. 2012. Pengaruh Intellectual Capital Dan Pengungkapannya Terhadap Nilai Perusahaan (Studi Empiris Pada Perusahaan Farmasi Di BEI). Jurnal Ilmiah Mahasiswa Akuntansi, 1(4), hal. 96-100.

Kartika, Martha and Saarce Elsye Hatane. 2013. Pengaruh Intellectual Capital Pada Profitibilitas Perbankan Yang Terdaftar Di Bursa Efek Indonesia Pada Tahun 2007-2011. Business Accounting Review, 1(2), hal. 14-25. 
Lestari, Nanik and Rosi Candra Sapitri. 2016. Pengaruh Intellectual Capital Terhadap Nilai Perusahaan. Jurnal Akuntansi, Ekonomi Dan Manajemen Bisnis, 4(1), hal. $28-33$.

Mehralian, Gholamhossein, Ali Rajabzadeh, and Hamid Reza Rasekh. 2012. Intellectual Capital and Corporate Performance in Iranian Pharmaceutical Industry. Journal of Intellectual Capital, 13(1), pp: 138-158.

Mondal, Amitava and Santanu Kumar Ghosh. 2012. Intellectual Capital and Financial Performance of Indian Banks. Journal of Intellectual Capital, 12(4), pp: 515530.

Neha, Simriti and Niladri Das. 2017. Impact Of Intellectual Capital On Business Performance : Evidence From Indian. Journal of Intellectual Capital, 15(1), pp: 232-243.

Ngari, James M., Robert Gichira, and Anthony Waititu. 2016. Analysis of the Relationship Between Intellectual Capital Accounting and Business Performance of Pharmaceutical Companies in Kenya. Confrence Paper April 2012. United Satete International University.

Nurdinia, Sheila Ramadhani. 2013. Pengaruh Intellectual Capital Terhadap Nilai Perusahaan. Kertas Kerja Pada Program Sarjana Fakultas Ekonomika Dan Bisnis Universitas Kristen Satya Wacana.

Pramestiningrum. 2013. Pengaruh Intellectual Capital Terhadap Kinerja Perusahaan Sektor Keuangan Yang Terdaftar Di Bursa Efek Indonesia Tahun 2009-2011. Skripsi Pada Program Sarjana Fakultas Ekonomika Dan Bisnis Universitas Dipenogoro.

Pratama, I.Gusti Bagus Angga and I.Gusti Bagus Wiksuana. 2016. Pengaruh Ukuran Perusahaan Dan Leverage Terhadap Nilai Perusahaan Dengan Profitabilitas Sebagai Variabel Intervening. E-Jurnal Manajemen Universitas Udayana, 5(2), hal. 1338-1367.

Preacher, Kristopher J. and Andrew F. Hayes. 2004. SPSS and SAS Procedures for Estimating Indirect Effects in Simple Mediation Models. Behavior Research Methods, Instruments, \& Computers, 36(4), pp: 717-731.

Pulic, Ante. 1998. Measuring the Performance of Intellectual Potential in the Knowledge Economy. Pp. 1-20 in the 2nd" McMaster World Congress on Measuring and Managing Intellectual Capital by the Austrian Team of 
ISSN: 2302-8556

E-Jurnal Akuntansi Universitas Udayana

Vol.26.3.Maret (2019): $1717-1740$

\section{Intellectual Potential.}

Putra, I.Gede Cahyadi. 2012. Pengaruh Modal Intelektual Pada Nilai Perusahaan Perbankan Yang Go Public Di Bursa Efek Indonesia. Jurnal Ilmiah Akuntansi Dan Humanika Universitas Mahasaraswati Denpasar, 2(1), hal. 1-22.

Putri, Khika Indira. 2017. Pengaruh Kinerja Keuangan Pada Nilai Perusahaan Dengan Good Corporate Governance Sebagai Variabel Pemoderasi. E-Jurnal Akuntansi Universitas Udayana, 2(1), hal. 1-28.

Razafindrambinina, Dominique and Talita Anggreni. 2011. Intellectual Capital and Corporate Financial Performance of Selected Listed Companies in Indonesia. Malaysian Journal of Economic Studies, 48(6), pp: 61-77.

Salvatore, Dominick. 2011. Ekonomi Manajerial Dalam Perekonomian Global. Buku 1 Edisi Kelima. Salemba Empat: Jakarta.

Simarmata, Rhoma and Subowo. 2016. Accounting Analysis Journal. Accounting Analysis Journal, 5(1), pp: 1-9.

Solikhah, Badingatus, H.Abdul Rohman, and Wahyu Meiranto. 2010. Implikasi Intellectual Capital Terhadap Financial Performance, Growth Dan Market Value; Studi Empiris Dengan Pendekatan Simplistic Specification. Makalah Disampaikan Dalam Simposium Nasional Akuntansi XIII, hal. 1-29.

Subkhan and Dyah Pitaloka Citraningrum. 2010. Pengaruh Ic Terhadap Kinerja Keuangan Perusahaan Perbankan Periode 2005-2007. Jurnal Dinamika Akuntansi, 2(1), hal. 30-36.

Sudibya, Diva Cicilya Nunki Arun and MI Mitha Dewi Restuti. 2014. Pengaruh Modal Intelektual Terhadap Nilai Perusahaan Dengan Kinerja Keuangan Sebagai Variabel Intervening. Jurnal Manajemen Dan Bisnis, 18(1), hal. 14-29.

Sunarsih, Ni Made and Ni Putu Yuria Mendra. 2012. Pengaruh Modal Intelektual Terhadap Nilai Perusahaan Dengan Kinerja Keuangan Sebagai Variabel Intervening Pada Perusahaan Yang Terdaftar Di Bursa Efek Indonesia. Makalah Disampaikan Dalam Simposium Nasional Akuntansi XV, Banjarmasin, 20-23 September.

Tan, Hong Pew, David Plowman, and Phil Hancock. 2007. Intellectual Capital and Financial Returns of Companies. Journal of Intellectual Capital, 8(1), pp: 7695. 
Ulum, Ihyaul. 2007. Pengaruh Intellectual Capital Terhadap Kinerja Keuangan Perusahaan Perbankan Di Indonesia. Tesis Pada Program Sarjana Fakultas Ekonomi Dan Bisnis Universitas Airlangga.

Wahyu, Widarjo. 2011. Pengaruh Modal Intelektual Dan Pengungkapan Modal Intelektual Pada Nilai Perusahaan. Disampaikan Dalam Simposium Nasional Akuntansi XIV, hal. 21-22.

Yuniasih, Ni Wayan, Dewa Gede Wirama, and I.Dewa Nyoman Badera. 2011. Pengaruh Modal Intelektual Pada Kinerja Pasar Perusahaan (Studi Empiris Pada Perusahaan Keuangan Yang Terdaftar Di Bursa Efek Indonesia). Jurnal Ilmiah Akuntansi Dan Bisnis, 6(2), hal. 1-24.

Zulyati dan Arya, Ngurah. 2011. Intellectual Capital Dan Kinerja Keuangan Perusahaan. Dinamika Keuangan Dan Perbankan, 3(1), hal. 113-125. 